\title{
The dark side of soft tissues: unexpected inorganic carbonate in the invasive slipper limpet Crepidula fornicata and its implications for stable isotope interpretations
}

\author{
Androuin Thibault ${ }^{1,}{ }^{*}$, Dubois Stanislas ${ }^{1}$, Decottignies Priscilla ${ }^{2}$, Pelleter Ewan ${ }^{3}$, Carlier Antoine ${ }^{1}$
}

${ }^{1}$ IFREMER, DYNECO-LEBCO; ZI Pointe du Diable 29280 Plouzané France

${ }^{2}$ University of Nantes, Lab. Mer Molécules Santé; EA 2160, 2 rue de la Houssinière 44322 Nantes

Cedex 3 France

${ }^{3}$ IFREMER, REM-UGM-LGM; ZI Pointe du Diable 29280 Plouzané France

* Corresponding author : Thibault Androuin, email address : thibault.androuin@ifremer.fr

\begin{abstract}
:
Rationale

Stable isotopic analysis is extensively used in trophic ecology. Inorganic carbonates, usually originating from shell fragments, are routinely removed from samples using an acid treatment because they affect $\delta 13 \mathrm{C}$ values. However, acid treatment can also change $\delta 15 \mathrm{~N}$ values. For some taxa such as molluscs, the general assumption is that acid pre-treatment is not necessary since their shell is easily dissected from soft tissues and represents the only source of inorganic carbonates. However, other sources of non-dietary carbon (e.g., intracellular inorganic carbon) enriched in $13 \mathrm{C}$ thus get overlooked.
\end{abstract}

Methods

Soft tissues (foot) of the invasive gastropod Crepidula fornicata of different size classes were analysed for their $\delta 13 \mathrm{C}$ and $\delta 15 \mathrm{~N}$ values with and without acid pre-treatment using isotope ratio mass spectrometry. In toto microscopic investigations coupled with acid treatment, scanning electron microscopy and energy dispersive spectroscopy were used to highlight the presence of inorganic carbonate. A correction model was derived and applied to existing stable isotope data for $C$. fornicata. We used both seasonal variations in $\delta 13 \mathrm{C}$ signatures and mixing model outputs to assess the error in $\delta 13 \mathrm{C}$ values.

Results

Acid pre-treatment had a significant effect on the stable isotope compositions of $C$. fornicata foot tissue, especially on $\delta 13 \mathrm{C}$ values: isotopic differences increased with size, up to $3 \%$ for large females. No effect was detected for small (below $\sim 20 \mathrm{~mm}$ ) and motile males. In toto microscopic analysis revealed the presence of small spherules of inorganic carbonate, hence explaining the differences in $\delta 13 \mathrm{C}$ values. Mixing model outputs and seasonal variation of $\delta 13 \mathrm{C}$ values showed that untreated samples can lead to large misinterpretations about diet proportions and degree of trophic niche overlap, respectively. 


\section{Conclusions}

Spherules of inorganic carbonate in $C$. fornicata soft tissues are likely to be linked with motility of this species and their mucus production. We recommend assessing the presence of inorganic carbonate in soft tissue of sessile gastropods. 


\section{Introduction}

Stable isotope (SI) analysis has been increasingly used in ecology for several decades ${ }^{2,3}$, especially to infer organic matter pathways in ecosystems, trophic positions of species, or animal movement ${ }^{4}$. Among the isotope ratios used in this way, the $\delta^{13} \mathrm{C}$ value is one of the most frequently employed in marine trophic ecology, as the small fractionation $(\sim 1 \%$ ) between a consumer and its diet makes it possible to trace the origin and fate of organic carbon ${ }^{4-6}$. SI analysis has been popularized worldwide by an increasing number of stable isotope facilities and a steadily falling analytical cost. As a result, because sample preparation is now a routine procedure, it may suffer from a lack of care and attention. Two major welldocumented biases can occur when preparing samples for SI analysis: a high storage lipid content ${ }^{7}$ and the presence of non-dietary carbon, such as inorganic carbonates ${ }^{1}$. In the animal kingdom, some hard structures are composed of inorganic carbonates, which are isotopically 'heavier' (i.e., enriched in ${ }^{13} \mathrm{C}$ ) relative to dietary organic carbon. To cope with potential carbonate contamination, scientists usually use an acid treatment prior to SI analysis $8-13$

For some taxa such as molluscs, ecologists take the easy approach of carefully removing external/internal shells and other hard structures (operculum, calcified radula). In many cases, the muscular part of the body (i.e., the foot and adductor muscles) is thus dissected out to avoid using acid treatment. Supposedly, dissection saves time over acid treatment, which poses a potential risk of affecting isotopic ratios ${ }^{8,13}$. Choosing this common method makes the assumption that soft tissues do not contain inorganic carbonates. However, inorganic carbonates in the form of calcium spherules have been shown to be present in different organs, e.g., in the foot muscle, arteries and digestive glands of terrestrial gastropods ${ }^{14-16}$, and also in the gills, mantle and digestive glands of freshwater bivalves ${ }^{17,18}$. To our knowledge, the presence of calcium spherules has only been investigated in five species of marine gastropods ${ }^{19,20}$.

Among marine gastropods, the slipper limpet Crepidula fornicata is a model species in many scientific fields ${ }^{21}$. This gregarious animal lives in stacks of several individuals and forms characteristic subtidal banks ${ }^{22}$. C. fornicata is a hermaphroditic species that begins its benthic life as a male with low motility and then becomes a sessile female. Because of its introduction to many parts of the world and potential cascading effect on food web functioning, numerous studies have used SI analysis to investigate its diet and to infer interspecific trophic overlap. These include its potential trophic competition with native suspension feeders such as the scallop Pecten maximus ${ }^{23}$, or cultivated species such as the blue mussel Mytilus edulis or Pacific oyster Magallena gigas (formerly Crassostrea gigas) ${ }^{24-}$ ${ }^{27}$. Recent personal observations revealed unexpected and repeated bubbling occurred from a C. fornicata foot dissected and dropped into a $1 \mathrm{~N}$ hydrochloric acid solution. This gas emission strongly suggests the presence of overlooked inorganic carbonates in the soft tissues of $C$. fornicata.

Here, we investigated the effect of acid pre-treatment on the carbon and nitrogen SI compositions in soft tissue (foot) of $C$. fornicata. We looked for inorganic carbonates in the foot using in toto microscopic investigation. The relationship between the $\delta^{13} \mathrm{C}$ deviation and individual size was quantified and a correction model proposed to correct for potential bias. 
We also assessed potential ecological pitfalls and misinterpretations between corrected and uncorrected data using both mixing model outputs and seasonal variations in ${ }^{13} \mathrm{C}$ signatures.

\section{Materials and methods}

2.1 Sample collection and preparation for stable isotope analysis

Forty-one Crepidula fornicata individuals ranging from 10.4 to $39.8 \mathrm{~mm}$ in total length were collected in the bay of Brest, France, in June 2015 (48 23.36068' N, 004 23.86901' W). For each individual, the soft tissues were carefully removed from the shell to avoid breaking small pieces of the septa (thin calcareous part of the shell). The foot was then dissected out and cut into two equal parts, one was rinsed with MilliQ (Merck Millipore, Fontenay sous Bois, France) water and the second was sliced into small pieces, placed in a beaker containing $1 \mathrm{~N} \mathrm{HCl}$ until the bubbling stopped, and then rinsed with MilliQ water. All the samples were freeze-dried and ground into homogenous powder using a ball mill (Retsch MM400, Eragny sur Oise, France).

\subsection{Stable isotope analysis}

Samples of approximately $400 \mu \mathrm{g}$ of powder per animal were weighed in tin capsules. SI analysis was performed on a Thermo Scientific Flash EA 2000 elemental analyser (Thermo Electron, Bremen, Germany) coupled to a Delta V Plus mass spectrometer in continuous flow (Thermo Electron) at the Pôle de Spectrométrie Océan (PSO, Plouzané, France). Organic carbon was expressed as percentage of the total organic matter, and stable isotope ratios in standard $\delta$ notation based on international standards (Vienna Pee Dee Belemnite for $\delta^{13} \mathrm{C}$ values and atmospheric nitrogen for $\delta^{15} \mathrm{~N}$ values) according to the equation:

$$
\delta=(\text { Rsample/Rstandard })-1(\%)
$$

where $\mathrm{R}$ is ${ }^{13} \mathrm{C} /{ }^{12} \mathrm{C}$ or ${ }^{15} \mathrm{~N} /{ }^{14} \mathrm{~N}$.

International isotopic standards of known $\delta^{15} \mathrm{~N}$ and $\delta^{13} \mathrm{C}$ values were used: IAEA-600 caffeine, IAEA-CH-6 sucrose, and IAEA-N-1 and IAEA-N-2 ammonium sulphate. The experimental precision was estimated using the standard deviation of an internal standard (Thermo Acetanilide, $\mathrm{n}=8$ ), which indicated an analytical precision of $\pm 0.11 \%$ and \pm $0.07 \%$ for $\delta^{13} \mathrm{C}$ and $\delta^{15} \mathrm{~N}$ values, respectively.

2.3 In toto microscopic investigation

For microscopic investigations, we sampled small transverse sections $(\sim 1 \mathrm{~mm})$ of foot tissue from thirty adult $C$. fornicata individuals (mean length $=35 \pm 5 \mathrm{~mm}$ ). After observation under an optical microscope to find structures (i.e., spherules), we added one drop of $1 \mathrm{~N} \mathrm{HCl}$ between the slide and the plate. The presence of inorganic carbon was verified by observing dissolutions of the spherules and the accompanying gas emission. Scanning Electron Microscopy (SEM) and Energy Dispersive Spectroscopy (EDS) analyses were also performed to investigate the foot tissue of adult $C$. fornicata. SEM provides information about the surface topography of a sample, whereas EDS analysis gives a qualitative elemental analysis. Small pieces of dried samples $\left(50^{\circ} \mathrm{C}\right.$ for $\left.48 \mathrm{~h}\right)$ were mounted on pin stubs and 
coated with carbon or gold. SEM and EDS secondary electron images were then obtained with a FEI (Hillboro, OR, USA) Quanta 200 scanning electron microscope coupled with an OXFORD X-MAXN Silicon Drift Detector (detector size: $80 \mathrm{~mm}^{2}$; Oxford Instruments, Abingdon, UK) at the Laboratoire de Géochimie et Métallogénie of IFREMER (Plouzané, France).

\subsection{Data analysis}

Since the treated and non-treated samples were non-independent, and the values of pairdifferences normally distributed (Shapiro-Wilk, $p$-value $>0.2$ ), $\delta^{13} \mathrm{C}$ and $\delta^{15} \mathrm{~N}$ value differences between acid-treated and non-treated samples were tested using paired t-tests. The relationships between isotopic deviations due to acid treatment and individual size were investigated using both linear and exponential models. The best fit was chosen based on the coefficient of determination. Differences in paired $\delta^{13} \mathrm{C}$ values (i.e., $\delta^{13} \mathrm{C}$ values of the treated and untreated halves of a given sample) were plotted on individual size. The relationship thus obtained was used as a correction model. Correction consists in replacing the unknown parameter " $x$ " in the equation with the size of the individual. This correction factor $y$ should be subtracted from any $\delta^{13} \mathrm{C}$ value obtained from non-acidified samples. The percentage of organic carbon was compared between treatments and categories of $C$. fornicata (i.e., motile males, sessile males and sessile females) using a mixed-effect model to take into account repeated measurement in the two-factor analysis of variance. This model allows the incorporation of a random effect term in a linear model, which produces a correlation structure between measurements from the same individual ${ }^{28,29}$. Normality and homogeneity of residual variance were checked visually and post hoc comparisons were made using Tukey tests.

An isotopic mixing model allows the calculation of contributions of potential food sources to the diet of a species (Phillips et al ${ }^{30}$ ). In order to assess the influence of the carbonated spherules (which is neutralized by acid treatment) in the computation of dietary proportions of $C$. fornicata individuals of varying sizes, a mixing model was run using $\delta^{15} \mathrm{~N}$ values of untreated consumer samples and $\delta^{13} \mathrm{C}$ values of either treated or untreated consumer samples. We considered three potential food sources (marine suspended particulate organic matter, benthic diatoms and an association of macroalgae/C4 plants) and used realistic food source isotopic ratios and trophic discrimination factors previously published by Decottignies et al. 24 (Table S1, supporting information). Although these authors considered a fourth potential food source (marine angiosperms Halimione sp. and Salicornia sp.), we did not include this in our mixing model due to its very low contribution to the diet of filter feeders in their case study ${ }^{25}$. The dual element $\left(\delta^{13} \mathrm{C}, \delta^{15} \mathrm{~N}\right)$, three-source, mass-balance, linear mixing model can be described by the following equations:

$\delta^{13} \mathrm{C}_{\mathrm{m}}=\mathrm{f}_{1} \delta^{13} \mathrm{C}_{1}+\mathrm{f}_{2} \delta^{13} \mathrm{C}_{2}+\mathrm{f}_{3} \delta^{13} \mathrm{C}_{3}$

$\delta^{15} \mathrm{~N}_{\mathrm{m}}=\mathrm{f}_{1} \delta^{15} \mathrm{~N}_{1}+\mathrm{f}_{2} \delta^{15} \mathrm{~N}_{2}+\mathrm{f}_{3} \delta^{15} \mathrm{~N}_{3}$

$1=f_{1}+f_{2}+f_{3}$,

where $f_{1}, f_{2}$ and $f_{3}$ are proportions of the three potential food sources. Because mixing models use a Bayesian approach that integrates uncertainty such as diet-tissue discrimination factors 
${ }^{30}$, classic statistical tests to assess mean or distribution differences are not relevant ${ }^{31}$. We used the interquartile range (IQR), which is a measure of statistical dispersion ${ }^{32}$. The difference between the third and the first quartile is defined as an index of overlap between dietary proportions. In this study, we considered that two distributions of dietary proportions were different if the two corresponding IQRs were non-overlapping.

We extracted $\delta^{13} \mathrm{C}$ values from ${ }^{25}$ to infer interspecific relationships between $C$. fornicata and Magallena gigas. The trophic niche overlap between species was investigated using seasonal $\delta^{13} \mathrm{C}$ values for both species. Differences between species were analysed using nonparametric Mann-Whitney tests since the data were not normally distributed. We focused on two specific seasons (winter-early summer and late summer) during which changes in trophic relationships are known to occur.

All statistical analysis were computed with the free software $\mathrm{R}^{33}$ using the ggplot ${ }^{34}$, nlme ${ }^{35}$, rcompanion ${ }^{28}$ and simmr packages ${ }^{36}$.

\section{Results}

3.1 Effect of acid treatment on $\delta^{13} \mathrm{C}$ and $\delta^{15} \mathrm{~N}$ values

The $\delta^{15} \mathrm{~N}$ values of foot tissue increased linearly with individual size for both untreated and acid-treated samples, with a steeper slope for acid-treated samples (Figure 1A). The $\delta^{13} \mathrm{C}$ values increased exponentially with individual size, with a greater slope for untreated samples (Figure 1B). Differences between untreated and acid-treated samples were significant for both nitrogen and carbon isotope ratios (paired t-test; $\mathrm{T}=4.63, p$-value $=$ 0.0001 and $\mathrm{T}=3.87, p$-value $=0.0009$, respectively). To formalize isotopic deviation in untreated samples, a correction model was computed from the $\delta^{13} \mathrm{C}$ values using a three-order polynomial regression (Figure 1C).

The organic carbon content of the foot tissue was dependent on both treatment and $C$. fornicata development stage (significant interaction between treatment $\times$ stage: $\mathrm{F}=9.22, p$ value $<0.001$, Figure 2). Significantly lower organic carbon content was observed for both untreated sessile males and females (Figure 2).

\subsection{In toto microscopic investigation}

Numerous spherules of $\sim 30 \mu \mathrm{m}$ size consisting of granular material were observed in the foot tissue of all examined individuals $(n=30)$ (Figure 3A). The addition of one drop of $1 \mathrm{~N}$ $\mathrm{HCl}$ to the preparation triggered gas bubbles and the dissolution of the spherules (Figures 3B and C). After less than 3 minutes, all the spherules had dissolved (Figure 3D; and Figure S1, supporting information). We also performed the 'limewater' test to check for $\mathrm{CO}_{2}$ in the emitted gas. Fresh tissue of $C$. fornicata (foot) was crushed and put in an Erlenmeyer flask connected by a pipe to another filled with distilled water saturated in lime. $20 \mathrm{~mL}$ of $1 \mathrm{~N}$ hydrochloric acid was added to the tissue and this Erlenmeyer flask then hermetically closed. After 1 minute, bubbles came through the pipe into the limewater, which became cloudy thus indicating the presence of $\mathrm{CO}_{2}$. Further observations revealed the presence of similar spherules in the entire animal, but less abundant than in the foot tissue. Spherules were clearly visible under the surface of the skin of dehydrated foot tissue (Figures 4A and B). Close-up images of a broken part of this tissue sample highlighted the internal composition of 
the spherules. These consist of a multitude of tiny balls of about $1 \mu \mathrm{m}$ diameter (Figure 4C). EDS qualitative analysis indicated that these spherules are composed of carbon, oxygen, calcium and magnesium.

3.3 Presence of spherules in relation to the substrate of $C$. fornicata

When removed from underlying shell substrates, $C$. fornicata individuals leave a hard, white (more or less pronounced) deposit, which perfectly matches their foot imprint (Figure 5A). This deposit also reacts with acid and produces gas, but was not observed for five supplementary individuals inhabiting non-calcareous substrates (Figure 5B). Nevertheless, these indiyiduals all showed the same pattern of calcareous spherule distribution in their bodies (Figure 5C) with comparable amounts in the foot (Figure 5D).

\subsection{Implications for diet composition assessment of C. fornicata}

The estimation of the contributions of potential food sources to the diet of $C$. fornicata (i.e., Marine POM, Benthic diatoms and Macroalgae and C4 plants) and the extent of change varied greatly depending on the $C$. fornicata size classes and sources (Figure 6), whether corrected or uncorrected $\delta^{13} \mathrm{C}$ values were used. Due to an overall small dietary contribution, the proportion of benthic diatoms was little affected by acid treatment, except for the largest size class 36-40 mm (Figure 6A). The dietary proportions of macroalgae and C4 plants showed clear differences for individuals larger than $30 \mathrm{~mm}$ (Figure 6B). Finally, marine POM contributions showed the highest differences between uncorrected and corrected samples, with increasing ranges from $25 \mathrm{~mm}$ and above (Figure 6C). For the largest individuals $(36-40 \mathrm{~mm})$, corrected $\delta^{13} \mathrm{C}$ values revealed that contributions were overestimated for benthic diatoms (53\%) and macroalgae/plants $(22 \%)$ but under-estimated for marine POM (43\%), when comparing with uncorrected values.

3.5 Implications in interspecific trophic overlap assessment

Inter-specific isotopic differences between the two suspension-feeding species $C$. fornicata and $M$. gigas showed opposite seasonal patterns when comparing corrected and uncorrected $\delta^{13} \mathrm{C}$ values (Figure 7). For instance, during late summer, $\delta^{13} \mathrm{C}$ value differences between oysters and slipper limpets were non-significant when considering uncorrected values of $C$. fornicata, but were significant after correction. Conversely, from winter to early summer, significant differences became non-significant after correction.

\section{Discussion}

The present study aimed to investigate the effect of acidification of soft tissues (foot) on carbon and nitrogen stable isotope ratios in slipper limpet $C$. fornicata, a common and widespread invasive gastropod. We coupled isotopic compositions and microscopic observations to quantify the effect of the acid pre-treatment on $\delta^{13} \mathrm{C}$ and $\delta^{15} \mathrm{~N}$ values.

4.1 The need for acid treatment in $\delta^{13} \mathrm{C}$ value assessments in $C$. fornicata

Acid pre-treatment had no effect on either $\delta^{13} \mathrm{C}$ or $\delta^{15} \mathrm{~N}$ values for small sizes of $C$. fornicata. For individual sizes above $\sim 20 \mathrm{~mm}$, the difference between treated and untreated samples increased linearly up to $0.6 \%$ or for $\delta^{15} \mathrm{~N}$ values, and exponentially up to $3 \%$ for $\delta^{13} \mathrm{C}$ values. 
These values are higher than those found in other investigations on acid treatments in gastropods. As reviewed in ${ }^{1}, \delta^{13} \mathrm{C}$ values in untreated gastropods had a mean deviation of 0\%o ( \pm 0.09$)$ compared with acidified samples, whereas $\delta^{15} \mathrm{~N}$ values were slightly higher, by $0.14 \%$ o $( \pm 0.09)$. Although a low concentration solution of hydrochloric acid $(1 \mathrm{~N})$ is not supposed to significantly transform organic matter (by chemical reactions or loss of organic matter) or fractionate stable isotope ratios ${ }^{1}$, we cannot exclude the possibility that acid treatment may cause slight deviations of stable isotope ratios. Potential reactions include solubilisation of acid-soluble organic carbon ${ }^{37}$, break-up of complex compounds such as amino acids and subsequent loss in rinses ${ }^{13}$, and volatilization ${ }^{38}$ or fractionation of organic carbon ${ }^{11}$. This is why many authors have stressed the need for a common sample preparation protocol in stable isotope studies ${ }^{39}$.

The largest individuals in this study were $40 \mathrm{~mm}$ in length, but $C$. fornicata can reach $50 \mathrm{~mm}$ ${ }^{40}$. As a result, one could expect even higher differences in $\delta^{13} \mathrm{C}$ values for larger adults, although extrapolating the correction beyond $40 \mathrm{~mm}$ has not been validated here. Acidified samples have higher organic carbon content per unit weight than non-acidified ones $(27 \pm 3 \%$ vs $41 \pm 1 \%$ for sessile female), indicating that organic and/or inorganic carbon reacts with acid. Gas releases and decreases in inorganic carbon during acidification suggest that $C$. fornicata foot tissue contains inorganic carbonates in higher concentrations in sessile individuals than in motile ones.

When dealing with molluscs in general and gastropods in particular, the inorganic carbon content is expected to originate from shell fragments. Isotopic investigations on C. fornicata have been carried out either on undissected animals rinsed with $1 \mathrm{~N} \mathrm{HCl}^{24-27}$, or on dissected animals without acid treatment ${ }^{23,41}$. In six out of seven studies, inorganic carbonates in the soft tissues were not dissolved by acid, hence generating measures falsely-enriched in ${ }^{13} \mathrm{C}$ in these studies (Table S2, supporting information). We found only one study in the literature likely to obtain comparable results for $\delta^{13} \mathrm{C}$ values: ${ }^{42}$ used freeze-dried powder with $1.2 \mathrm{~N}$ $\mathrm{HCl}$ solution directly in silver cups as an acidification process. This treatment allows a total dissolution of inorganic carbonates from the sample, giving a mean $\delta^{13} \mathrm{C}$ value of $-19.7 \%$, which is in the same range as our acid-treated samples. As a result, we recommend measuring $\delta^{13} \mathrm{C}$ and $\delta^{15} \mathrm{~N}$ values in two different ways: untreated samples for nitrogen and acidified samples for carbon. In order to allow perfect penetration of acid and avoid any loss of organic carbon during rinsing, we also encourage using in-cup acidification ${ }^{8}$.

\subsection{Origins of inorganic carbonates in Crepidula fornicata soft tissue}

In gastropod taxa, the foot is the organ of movement and/or fixation onto the substrate. It is therefore in direct contact with the environment. For freshwater gastropods, calcium is a limiting element taken up through the foot and stored as spherules in the soft tissues ${ }^{43}$. Because mucous secreted by the foot combines with calcium ${ }^{44}$, it has been suggested that calcium is absorbed percutaneously from the substrate and stored in the foot ${ }^{44-46}$. In freshwater gastropods, calcium deposits are mostly known to play roles in $\mathrm{pH}$ homeostasis ${ }^{47}$, and to a lesser extent in hemocyte reactions to particle or toxic invasions ${ }^{48}$. Unlike freshwater, seawater is not calcium limited and marine molluscs are not expected to use calcium storage processes for homeostasis regulation. In the few studies focusing on calcium deposits in marine gastropods, spherules were investigated for their metal detoxification 
capacities ${ }^{19,20}$. Interestingly, an investigation of feeding processes and the use of mucus in particle processing in $C$. fornicata by ${ }^{49}$ clearly showed white dots on the ventral surface (see Figure 1 in $\left.{ }^{49}\right)$. Although this previous study was not designed to investigate calcium spherules, high quality micrographs of living animals are a good way of revealing these spherules.

Ecological traits, and specifically the loss of motility of developing C. fornicata, could provide an explanation for the presence of calcareous spherules in soft tissues. Ontogenic histological changes have already been described for another Crepidula species ${ }^{50}$. A specific type of mucocyte is indeed preferentially associated with females and linked to their greater adhesive capacity on the substrate. Interestingly, these authors mentioned a homogenous granular material in two kinds of mucocytes of the epithelial and sub-epithelial tissue. Since calcium binds with mucous to form calcium carbonates ${ }^{44}$, it is likely that this granular material corresponds to inorganic carbonates, as confirmed by the EDS analysis in the present study. Interestingly, we also detected a large amount of magnesium in our samples (Magnesium/Calcium ratio 5). While this was beyond the scope of our present study, future experiments should investigate the origin of such great quantity of magnesium in the soft tissue of $C$. fornicata. The nature of the substrate should also be examined. The adhesive capacity of mucus increases with viscosity and acidity ${ }^{51,52}$. Because $C$. fornicata spends its entire life ( 10 years) on the same substrate, it is expected to show high mucus acidity (i.e., high adhesive capacity). A calcareous substrate associated with mucus acidity also potentially explains the calcareous concretion on the underlying shell and increases the percutaneous uptake of carbonates by the foot (Figure 5A). However, qualitatively comparable amounts of spherules were also found in C. fornicata inhabiting non-calcareous substrates (Figures 5BD), which suggests that the accumulation of inorganic carbonates is linked to intrinsic physiological processes rather than to the type of substrate. In our study we differentiated motile and sessile males because males larger than $20 \mathrm{~mm}$ are found in their final position, on top of female shells, and become sessile although they are still male. Because motility is not strictly related to sexual differentiation, we also suggest that the increasing adhesive capacity of the species in relation to its gregarious behaviour explains the concentration of inorganic carbonates in its soft tissues.

Similar histological observations were made for individuals of $C$. fornicata collected in the bays of Mont-Saint-Michel and Bourgneuf (France), suggesting again that they are the result of an intrinsic physiological process rather than local conditions. Because the presence of inorganic carbonates is related to biological traits of $C$. fornicata (protandry, motility and mucus production), local environmental conditions could enhance or lower this physiological process and ultimately slightly affect the correction factor provided here. The amplitude of the deviation in ${ }^{13} \mathrm{C}$ might therefore need to be characterized by replicating the same protocol in additional study sites. Preliminary results also showed that other calyptraeidae species such as Calyptraea chinensis - have similar biological traits (i.e., sessile and suspensionfeeding) but should be processed with caution as the correction factor provided here cannot readily be applied to other species.

4.3 Trophic implications

This article is protected by copyright. All rights reserved. 
Differences in isotopic composition between treated and untreated samples potentially indicate large ecological differences and could therefore have consequences for data interpretation. Results from the literature have commonly shown C. fornicata to be higher in ${ }^{13} \mathrm{C}$ than other filter-feeder species, suggesting a higher proportion of ${ }^{13} \mathrm{C}$-enriched food sources, such as benthic microalgae, in their diet. Here, we showed using published data 25 that the contribution of microalgae to the diet of $C$. fornicata has generally been overestimated (up to 53\%), while, conversely, the contribution of marine POM has been underestimated (up to 43\%). Interpretations in benthic-pelagic coupling regarding allochtonous versus autochtonous food sources are therefore compromised. Mixing models computed with corrected $\delta^{13} \mathrm{C}$ values also showed higher similarities with those of other suspension-feeding species such as the Pacific oyster Magallana gigas, and a potentially higher trophic competition when food is limited. The two species were thought to compete for food in winter and spring ${ }^{25}$, but corrected contributions of food sources show that their overlap in diet is higher than previously estimated. Conversely, they do not seem to overlap in late summer. It is thus possible that the invasive slipper limpet $C$. fornicata could be a stronger trophic competitor than previously reported. It is worth noting that we used a correction model based on foot tissue only, whereas ${ }^{25}$ based their analysis on the whole body. However, because microscopic observations revealed the presence of calcareous concretions in several types of tissue (Figure 5C) and because the foot represents 55 to $65 \%$ of the body mass of $C$. fornicata $^{23}$, this difference should not weaken our conclusions.

\section{Conclusions and recommendations}

Crepidula fornicata contains a significant proportion of inorganic carbonates in its soft tissue. Although SI is now commonly used in trophic ecology studies, we still need to be careful about sample preparation, which should be species-specific. We recommend that researchers using SI take into consideration that "soft tissue" does not necessarily mean "without inorganic carbonate", e.g., by applying the quick and easy 'Champagne test' ${ }^{1}$ on a small piece of sample. This test could make it possible to target specific parts of the tissue of interest, which could be dissected without risk of 'carbonate pollution', thus avoiding serious misinterpretations when inferring conclusions from SI analysis.

\section{Acknowledgements}

The authors are grateful to the staff of the stable isotope facility (Pole de Spectrometrie Ocean) for technical help and Gilles Chazot for fruitful discussion about spherule composition. TA was funded by an Ifremer-Region Bretagne $\mathrm{PhD}$ grant. AC and SFD received a grant from the national EC2CO-DRIL initiative. We would also like to thank three anonymous reviewers for their pertinent comments that greatly improved the manuscript. 


\section{Bibliography}

1. Schlacher TA, Connolly RM. Effects of acid treatment on carbon and nitrogen stable isotope ratios in ecological samples: a review and synthesis. Methods in Ecology and Evolution. 2014;5(6):541-550. doi:10.1111/2041-210X.12183

2. Fry B, Sherr EB. $\delta^{13} \mathrm{C}$ measurements as indicators of carbon flow in marine and freshwater ecosystems. Contribution in Marine Science. 1984;27:13-47.

3. Herman P, Middelburg J, Widdows J, Lucas C, Heip C. Stable isotopes as trophic tracers: combining field sampling and manipulative labelling of food resources for macrobenthos. Marine Ecology Progress Series. 2000;204:79-92. doi:10.3354/meps204079

4. Fry B. Stable Isotope Ecology. New York, NY: Springer; 2006.

5. DeNiro MJ, Epstein S. Influence of diet on the distribution of carbon isotopes in animals. Geochim Cosmochim Acta. 1978;42(5):495-506. doi:10.1016/0016-7037(78)90199-0

6. Boecklen WJ, Yarnes CT, Cook BA, James AC. On the Use of Stable Isotopes in Trophic Ecology. Annual Review of Ecology, Evolution, and Systematics. 2011;42(1):411-440. doi:10.1146/annurev-ecolsys-102209-144726

7. Post DM, Layman CA, Arrington DA, Takimoto G, Quattrochi J, Montaña CG. Getting to the fat of the matter: models, methods and assumptions for dealing with lipids in stable isotope analyses. Oecologia. 2007;152(1):179-189. doi:10.1007/s00442-006-0630-x

8. Guerin AJ, Jensen AC, McGill RAR. Effects of distilled water rinsing on stable isotope ratios of acid-treated marine invertebrate (Paguridae) samples: Distilled water rinsing of acid-treated invertebrate samples. Rapid Commun Mass Spectrom. 2013;27(18):2051-2056. doi:10.1002/rcm.6659

9. Jacob U, Mintenbeck K, Brey T, Knust R, Beyer K. Stable isotope food web studies: a case for standardized sample treatment. Marine Ecology Progress Series. 2005;287:251-253. doi: $10.3354 /$ meps 287251

10. Jaschinski S, Hansen T, Sommer U. Effects of acidification in multiple stable isotope analyses: Acidification in stable isotope samples. Limnology and Oceanography: Methods. 2008;6(1):1215. doi:10.4319/lom.2008.6.12

11. Kennedy P, Kennedy H, Papadimitriou S. The effect of acidification on the determination of organic carbon, total nitrogen and their stable isotopic composition in algae and marine sediment. Rapid Commun Mass Spectrom. 2005;19(8):1063-1068. doi:10.1002/rcm.1889

12. Lorrain A, Savoye N, Chauvaud L, Paulet Y-M, Naulet N. Decarbonation and preservation method for the analysis of organic $\mathrm{C}$ and $\mathrm{N}$ contents and stable isotope ratios of low-carbonated suspended particulate material. Anal Chim Acta. 2003;491(2):125-133. doi:10.1016/S00032670(03)00815-8

13. Mateo MA, Serrano O, Serrano L, Michener RH. Effects of sample preparation on stable isotope ratios of carbon and nitrogen in marine invertebrates: implications for food web studies using stable isotopes. Oecologia. 2008;157(1):105-115. doi:10.1007/s00442-008-1052-8

14. Burton RF. The storage of calcium and magnesium phosphates and of calcite in the digestive glands of the pulmonata (Gastropoda). Comparative Biochemistry and Physiology Part A: Physiology. 1972;43(3):655-663. doi:10.1016/0300-9629(72)90252-6

15. Little C. Osmotic and ionic regulation in the prosobranch gastropod mollusc, Viviparus viviparus Linn. Journal of Experimental Biology. 1965;43:23-37.

16. Tompa AS, Watabe N. Calcified arteries in a gastropod. Calcified Tissue Research. 1977;22(1):159-172. doi:10.1007/BF02010355

17. Istin M, Girard JP. Carbonic anhydrase and mobilisation of calcium reserves in the mantle of lamellibranchs. Calcified Tissue Research. 1970;5(1):247-260. doi:10.1007/BF02017553

18. Pynnönen K, Holwerda DA, Zandee DI. Occurrence of calcium concretions in various tissues of freshwater mussels, and their capacity for cadmium sequestration. Aquatic Toxicology. 1987;10(2-3):101-114. doi:10.1016/0166-445X(87)90017-8

19. Mason AZ, Nott JA. The role of intracellular biomineralized granules in the regulation and detoxification of metal in marine gastropods with special reference to the marine prosobranch Littorina littorea. Aquatic Toxicology. 1981;1:239-256. 
20. Nott JA, Nicolaidou A. The Cytology of Heavy Metal Accumulations in the Digestive Glands of Three Marine Gastropods. Proc R Soc B: Biol Sciences. 1989;237(1288):347-362. doi:10.1098/rspb.1989.0053

21. Henry JQ, Lyons DC. Molluscan models: Crepidula fornicata. Current Opinion in Genetics \& Development. 2016;39:138-148. doi:10.1016/j.gde.2016.05.021

22. Barnes RSK, Coughlan J, Holmes NJ. A preliminary survey of macroscopic fauna, with particular reference to Crepidula fornicata. Proceedings of the Malacological Society of London. 1973;(40):253-275.

23. Richard J. Crepidula fornicata : un modèle biologique pour l'étude du rôle de la variabilité des caractères phénotypiques (reproduction, croissance et nutrition) sur les processus de colonisation en milieu marin. 2005. University of Geneva

24. Riera P, Stal L, Nieuwenhuize J. $\delta 13 \mathrm{C}$ versus $\delta 15 \mathrm{~N}$ of co-occurring molluscs within a community dominated by Crassostrea gigas and Crepidula fornicata (Oosterschelde, The Netherlands). Marine Ecology Progress Series. 2002;240:291-295. doi:10.3354/meps240291

25. Decottignies P, Beninger PG, Rincé Y, Riera P. Trophic interactions between two introduced suspension-feeders, Crepidula fornicata and Crassostrea gigas, are influenced by seasonal effects and qualitative selection capacity. Journal of Experimental Marine Biology and Ecology. 2007;342(2):231-241. doi:10.1016/j.jembe.2006.10.005

26. Decottignies P, Beninger PG, Rincé Y, Robins RJ, Riera P. Exploitation of natural food sources by two sympatric, invasive suspension-feeders: Crassostrea gigas and Crepidula fornicata. Marine Ecology Progress Series. 2007;334:179-192. doi:10.3354/meps334179

27. Lefebvre S, Marín Leal JC, Dubois S, et al. Seasonal dynamics of trophic relationships among co-occurring suspension-feeders in two shellfish culture dominated ecosystems. Estuarine, Coastal and Shelf Science. 2009;82(3):415-425. doi:10.1016/j.ecss.2009.02.002

28. Mangiafico SS. An R Companion for the Handbook of Biological Statistics. Vol Version 1.13.5. Rutgers Cooperative Extension, New Brunswick, NJ; 2015.

29. Zuur AF, Ieno EN, Walker NJ, Saveliev AA, Smith GM. Mixed Effects Models and Extensions in Ecology with R. Springer Science; 2009.

30. Phillips DL, Inger R, Bearhop S, et al. Best practices for use of stable isotope mixing models in food-web studies. Canadian Journal of Zoology. 2014;92(10):823-835. doi:10.1139/cjz-20140127

31. White JW, Rassweiler A, Samhouri JF, Stier AC, White C. Ecologists should not use statistical significance tests to interpret simulation model results. Oikos. 2014;123(4):385-388. doi:10.1111/j.1600-0706.2013.01073.x

32. Upton G, Cook I. Understanding Statistics. Oxford University Press. Butler \& Tanner Ltd, Frome and London; 1996.

33. R Core Team. R: A language and environment for statistical computing. 2012. http://www.Rproject.org/.

34. Wickham H. Ggplot2: Elegant Graphics for Data Analysis. Springer Nature. Springer International Publishing AG Switzerland; 2016.

35. Pinheiro JC, Bates DM. Mixed-Effects Models in S and S-PLUS. Springer; 2010.

36. Parnell AC, Phillips DL, Bearhop S, et al. Bayesian stable isotope mixing models: BAYESIAN STABLE ISOTOPE MIXING MODELS. Environmetrics. 2013;24:387-399. doi:10.1002/env.2221

37. Brodie CR, Leng MJ, Casford JSL, et al. Evidence for bias in C and $\mathrm{N}$ concentrations and $\delta 13 \mathrm{C}$ composition of terrestrial and aquatic organic materials due to pre-analysis acid preparation methods. Chem Geol. 2011;282(3-4):67-83. doi:10.1016/j.chemgeo.2011.01.007

38. Lohse L, Kloosterhuis RT, de Stigter HC, Helder W, van Raaphorst W, van Weering TC. Carbonate removal by acidification causes loss of nitrogenous compounds in continental margin sediments. Marine Chem. 2000;69(3-4):193-201. doi:10.1016/S0304-4203(99)00105-X

39. McCutchan JH, Lewis WM, Kendall C, McGrath CC. Variation in trophic shift for stable isotope ratios of carbon, nitrogen, and sulfur. Oikos. 2003;102(2):378-390. doi:10.1034/j.16000706.2003.12098.x 
40. Richard J, Huet M, Thouzeau G, Paulet Y-M. Reproduction of the invasive slipper limpet, Crepidula fornicata, in the Bay of Brest, France. Marine Biol. 2006;149(4):789-801. doi:10.1007/s00227-005-0157-4

41. Guérin L. La crépidule en rade de Brest: un modèle biologique d'espèce introduite proliférante en réponse aux fluctuations de l'environnement. University of Brest. 2004.

42. Dubois S, Blanchet H, Garcia A, et al. Trophic resource use by macrozoobenthic primary consumers within a semi-enclosed coastal ecosystem: Stable isotope and fatty acid assessment. Journal of Sea Research. 2014;88:87-99. doi:10.1016/j.seares.2014.01.004

43. Fournié J, Chétail M. Calcium Dynamics in Land Gastropods. American Zoologist. 1984;24(4):857-870. doi:10.1093/icb/24.4.857

44. Rao KP, Goldberg ED. Utilization of dissolved calcium by a pelecypod. Journal of Cellular and Comparative Physiology. 1954;43(3):283-292. doi:10.1002/jcp.1030430304

45. Kapur SP, Gibson MA. A histochemical study of calcium storage in the foot of the freshwater gastropod, Helisoma duryi eudiscus (Pilsbry). Canadian Journal of Zoology. 1968;46(5):987990. doi:10.1139/z68-138

46. Tanaka S, Hatano H. Biochemical studies on the pearl oyster, Pinctada martensii. IV. On the uptake of radioactive calcium by pearl oyster and its deposition on the pearl and the shell. $J$ Chem Soc Jap. 1955;76:602-605.

47. Sminia T, De With ND, Bos JL, Van Nieuwmegen ME, Witter MP, Wondergem J. Structure and function of the calcium cells of the freshwater pulmonate snail Lymnaea stagnalis. Netherlan Journal of Zoology. 1977;27(2):195-208.

48. Hinzmann MF, Lopes-Lima M, Bobos I, Ferreira J, Domingues B, Machado J. Morphological and chemical characterization of mineral concretions in the freshwater bivalve Anodonta cygnea (Unionidae). Journal of Morphology. 2015;276(1):65-76. doi:10.1002/jmor.20320

49. Shumway SE, Ward JE, Heupel E, et al. Observations of feeding in the common Atlantic slippersnail Crepidula fornicata L., with special reference to the "mucus net." Journal of Shellfish Research. 2014;33(1):279-291. doi:10.2983/035.033.0127

50. Chaparro OR, Bahamondes-Rojas I, Vergara AM, Rivera AA. Histological characteristics of the foot and locomotory activity of Crepidula dilatata Lamarck (Gastropoda: Calyptraeidae) in relation to sex changes. Journal of Experimental Marine Biology and Ecology. 1998;223(1):7791. doi:10.1016/S0022-0981(97)00151-2

51. Grenon J-F, Walker G. The histology and histochemistry of the pedal glandular system of two limpets, Patella vulgata and Acmaea tessulata (Gastropoda: Prosobranchia). Journal of the Marine Biological Association of the United Kingdom. 1978;58(04):803-816. doi:10.1017/S0025315400056770

52. Hunt S. Fine structure of the secretory epithelium in the hypobranchial gland of the prosobranch gastropod mollusc Buccinum undatum L. Journal of the Marine Biological Association of the United Kingdom. 1973;53(01):59-71. doi:10.1017/S0025315400056630

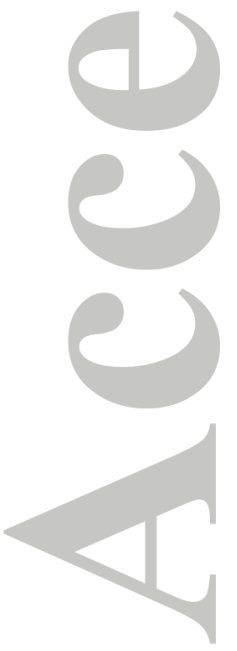



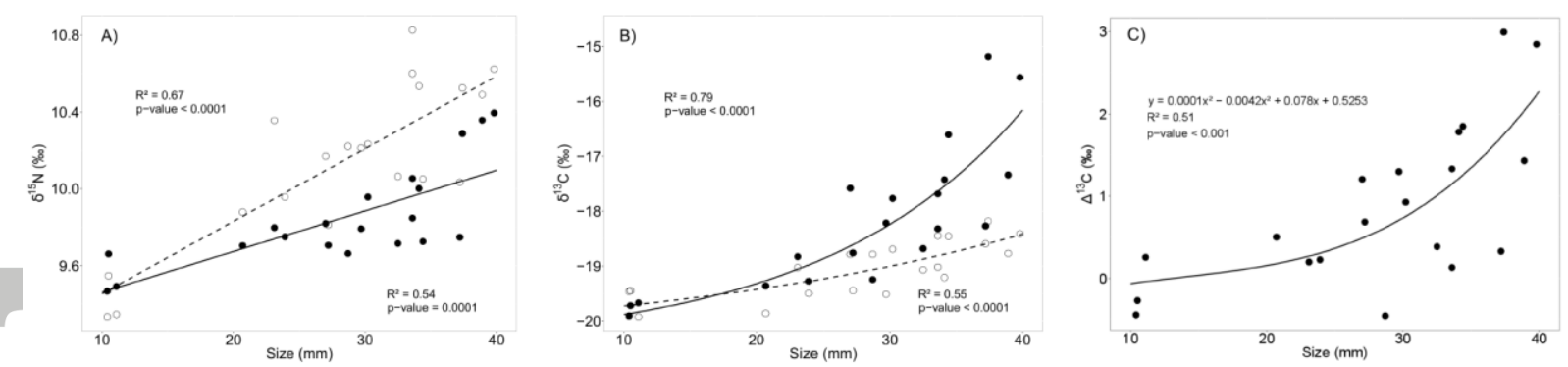

Figure 1: Relationships between nitrogen (A) or carbon (B) stable isotope ratios (\%o) measured in the foot of Crepidula fornicata and individual size for both untreated (filled circles) and acid-treated (open circles) samples. Correction model (C) showing the differences of $\delta^{13} \mathrm{C}$ value between acid-treated and untreated samples, according to individual size.
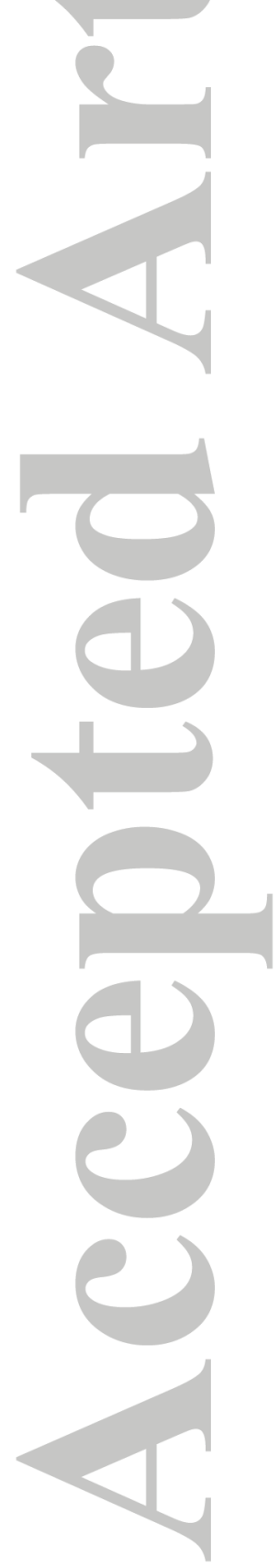


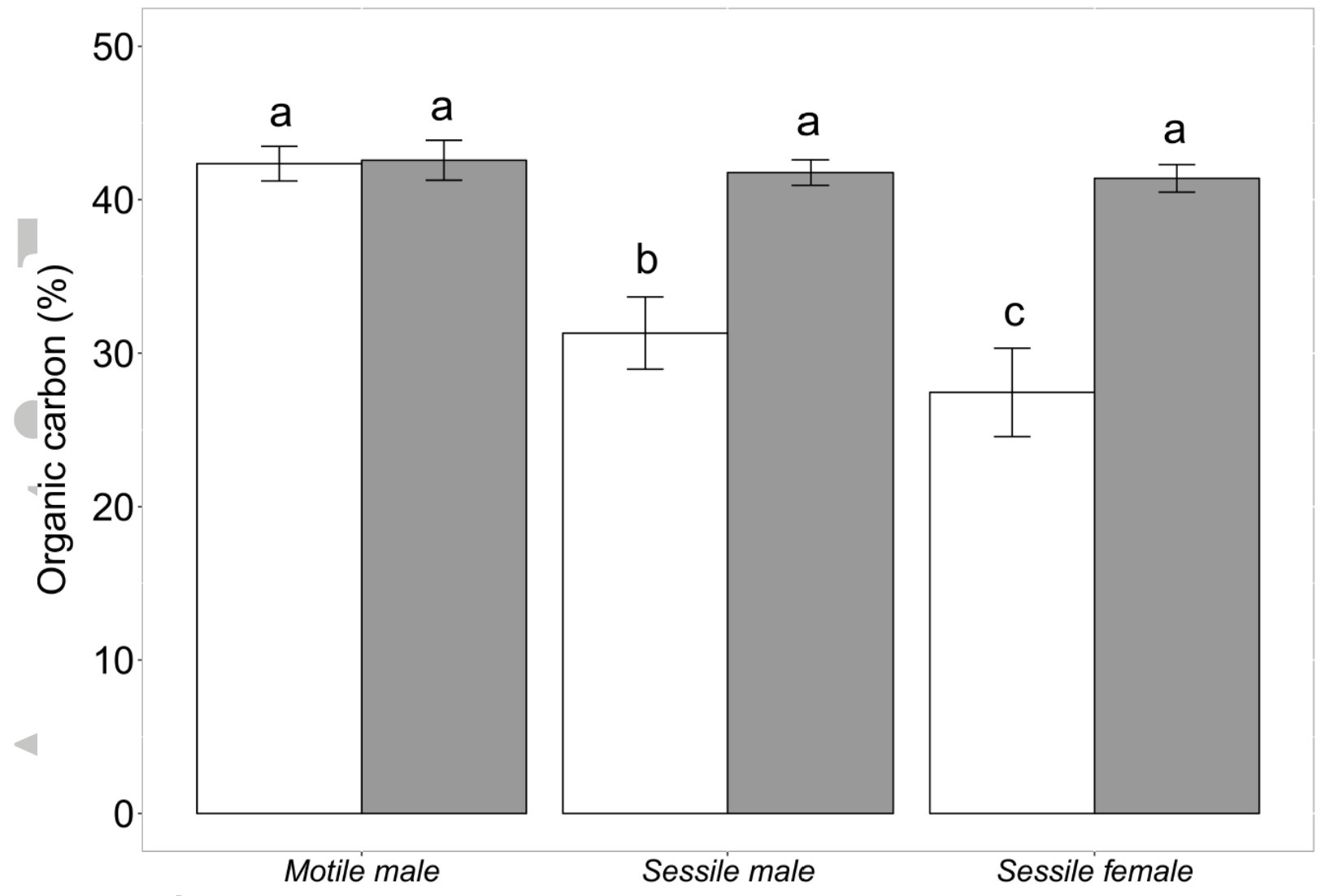

Figure 2: Organic carbon content $(\%)$ in foot of $C$. fornicata in untreated (white) and acid-treated (grey) samples. Significantly different groups are shown with different letters. 

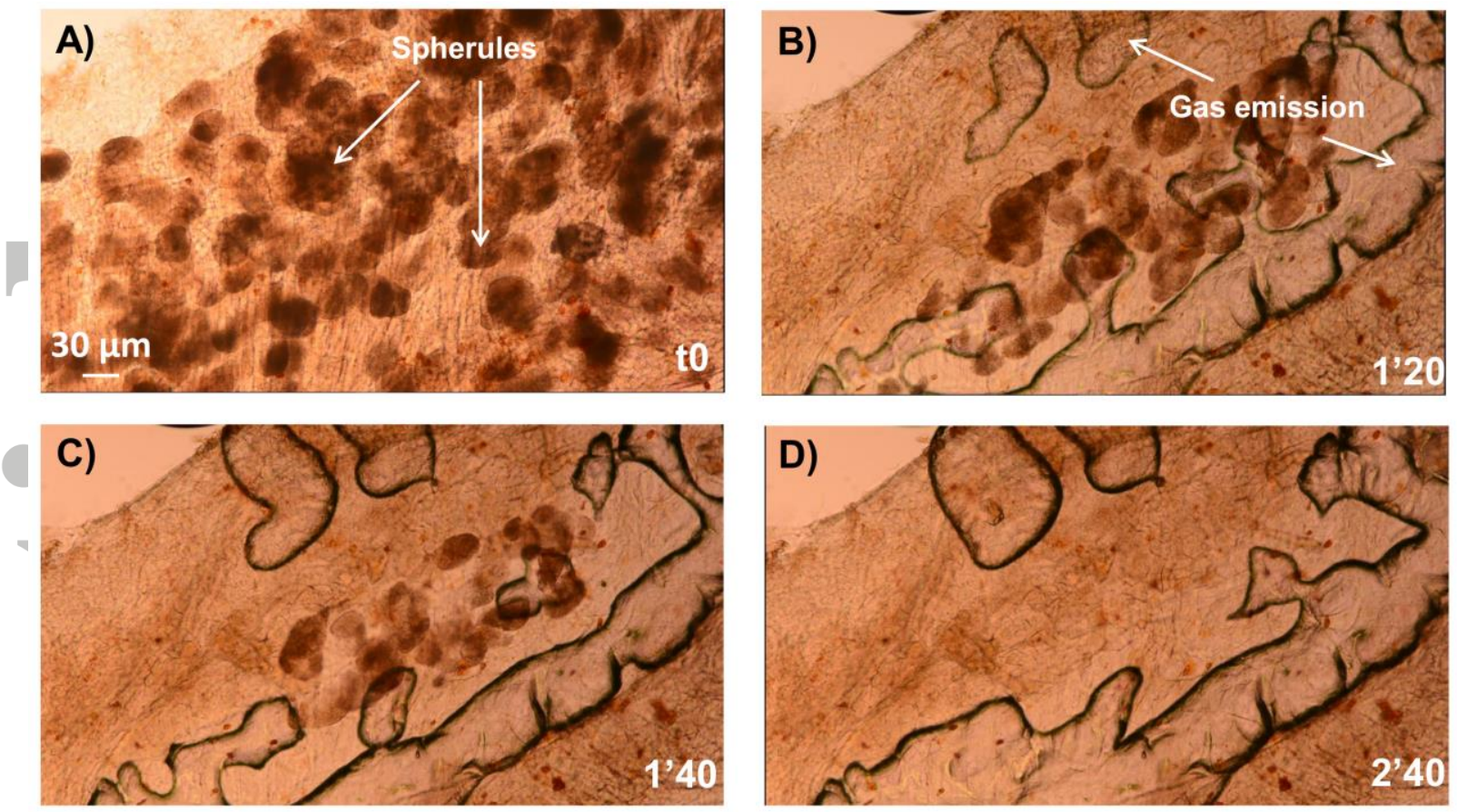

Figure 3: Example of an in toto histological cut of the slipper limpet $C$. fornicata foot before acidification (t0) (A) and 1'20 (B), 1'40 (C), and 2'40 (D) after 1M HCl acidification. Note the production of gas accompanied by the dissolution of calcareous spherules. All images are at the same scale.

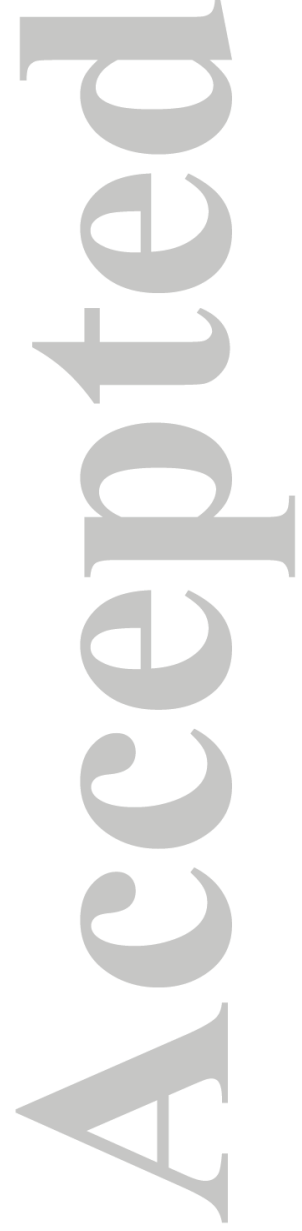



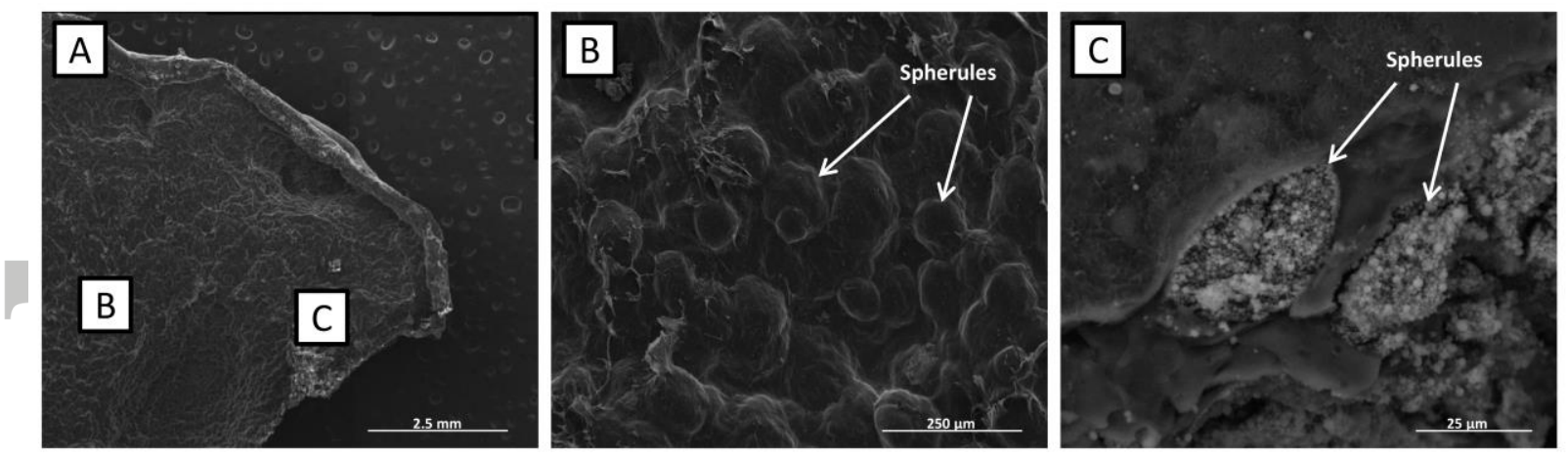

Figure 4: Scanning electron microscopy of the foot of adult of $C$. fornicata at different magnification levels.

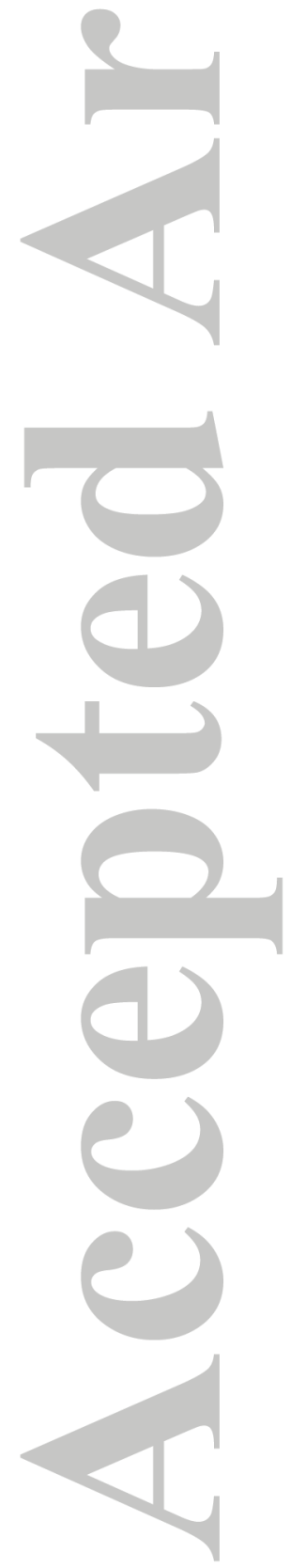



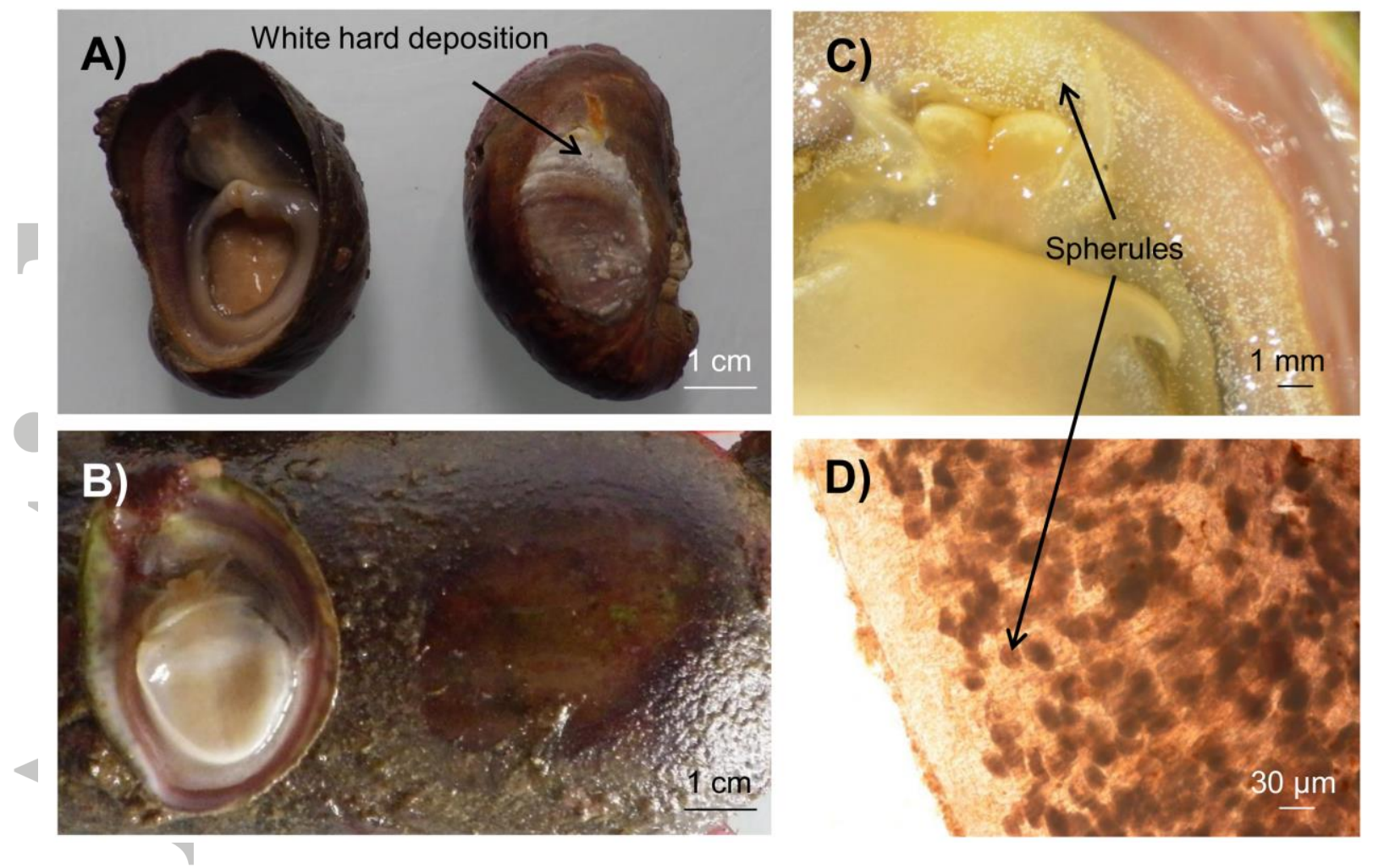

Figure 5: Images of the slipper limpet $C$. fornicata inhabiting a calcareous substrate (A) and a non-calcareous substrate (B). Calcareous concretions in $C$. fornicata soft tissue fixed on a non-calcareous substrate (C) and close-up of a foot tissue sample (D). 

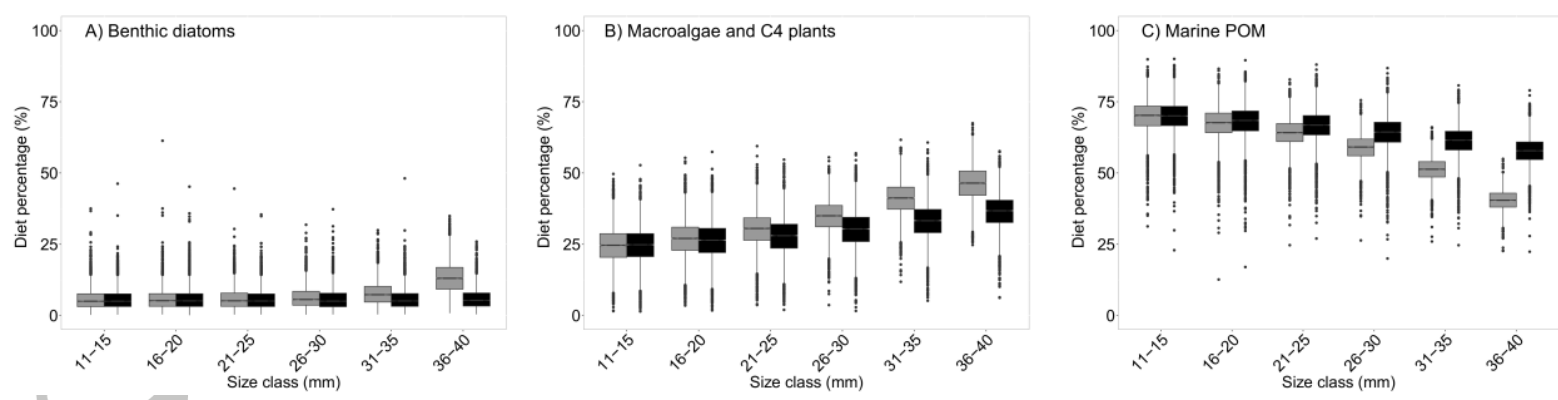

Figure 6: Relative contributions of benthic diatoms (A), macroalgae and C4 plants (B), and marine POM (C) to the diet of $C$. fornicata of six size classes calculated with uncorrected (grey) and corrected (black) $\delta^{13} \mathrm{C}$ values (data extracted from ${ }^{24}$ ). 

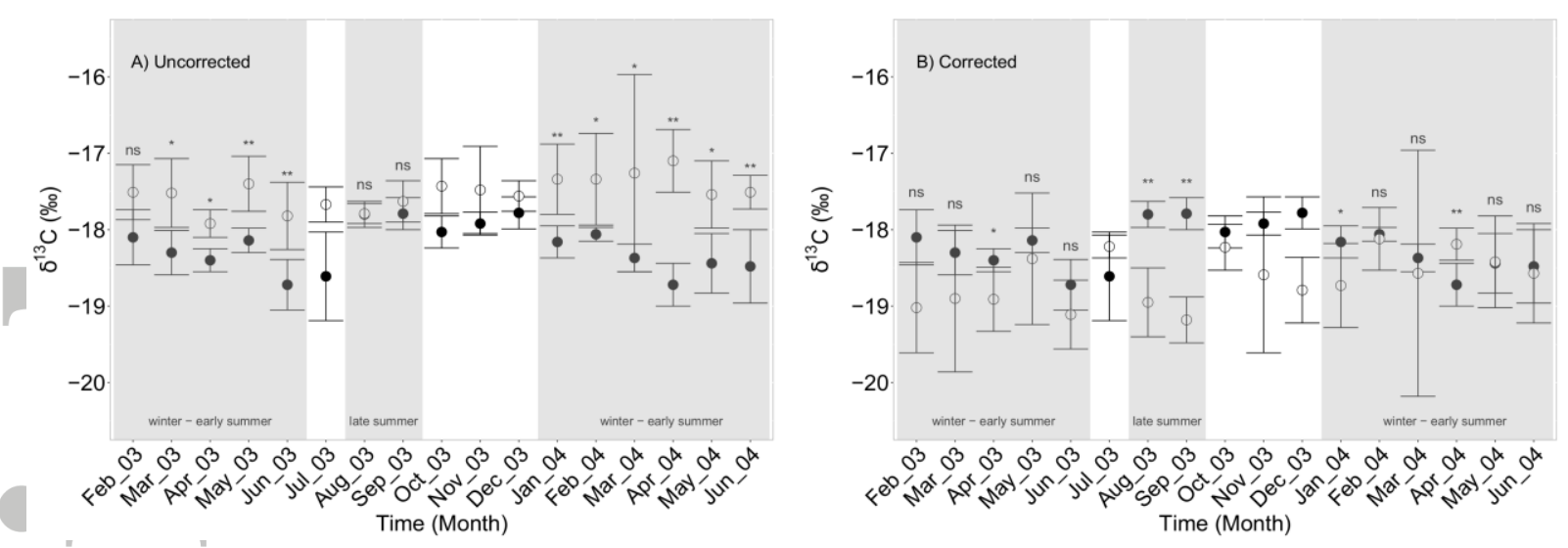

Figure 7: Seasonal variations of $\delta^{13} \mathrm{C}$ values measured for Crepidula fornicata (open circles) and Magallena gigas (filled circles) (mean $\pm \mathrm{SD} ; \mathrm{n}=5$ ). Interspecific $\delta^{13} \mathrm{C}$ comparisons are shown with uncorrected (A) and corrected (B) C. fornicata $\delta^{13} C$ values (data extracted from ${ }^{24}$ ). Asterisks show significant interspecific differences. ${ }^{\mathrm{ns}} p>0.05,{ }^{*}$ $p \leq 0.05, * * * 0.01$.
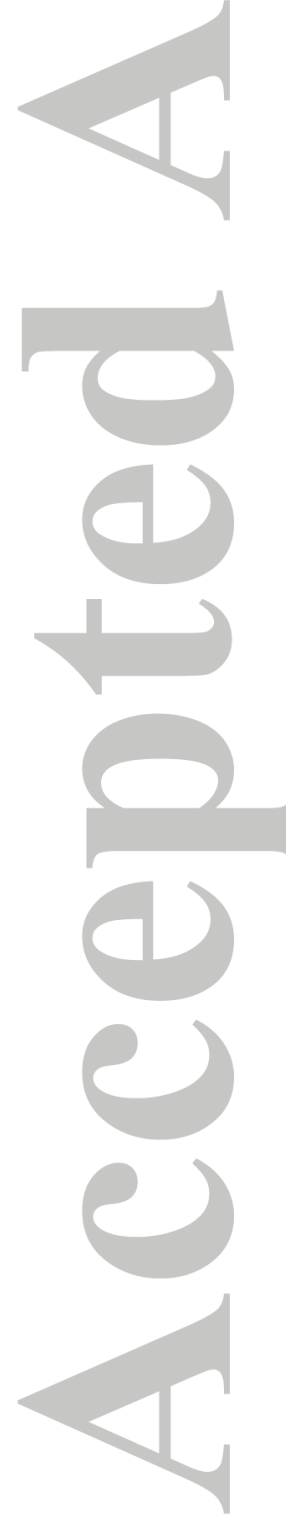

This article is protected by copyright. All rights reserved. 